Pamiętnik Literacki 2021, 1, s. 163-170

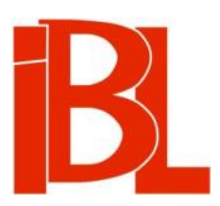

\title{
Nie tylko wokół aktu chrztu Stefana Grabińskiego
}

Dorota Samborska-Kukuć 
Pamiętnik Literacki CXII, 2021, z. 1, PL ISSN 0031-0514

DOI: $10.18318 / \mathrm{pl} .2021 .1 .10$

DOROTA SAMBORSKA-KUKUĆ Uniwersytet Łódzki

\section{NIE TYLKO WOKÓŁ AKTU CHRZTU STEFANA GRABIŃSKIEGO}

Każdy biogram Stefana Grabińskiego rozpoczyna się od oczywistości: urodził się w Kamionce Strumiłowej 26 II 1887. Jest to repetycja, powtarzana po Arturze Hutnikiewiczu, który - jako uczeń gimnazjalny autora Demona ruchu - był w posiadaniu wielu informacji wykorzystanych i niewykorzystanych w monografii o pisarzu $^{1}$. Jak sądzę, żaden $\mathrm{z}$ biografów Grabińskiego nie dotarł do autentycznego, znajdującego się w archiwum lwowskim, aktu urodzenia, zadowalając się przekazem wtórnym ${ }^{2}$. Dysponując tylko datą i miejscem urodzenia, badacz posiada wiedzę jednowymiarowa, w jakimś sensie hermetyczna, nie wyzwalająca prawie żadnego potencjału. Praktyka wyłącznie powtarzania, jakkolwiek nierzadka, wiążąca się tyleż z zaufaniem do poprzedników, co i z pewną pasywnością poznawczą, powoduje, że umykają często istotne detale biograficzne i genealogiczne. W metrykach znajdować się mogą bowiem wzmianki, które nie tylko same w sobie mają wartość dla rodowodu fundamentalna, tj. dokładna data i dokładne miejsce (często wraz $z$ adresem) przyjścia na świat, status społeczny rodziny, personalia i wiek rodziców (a czasem i dziadów), zawód i rodzaj zatrudnienia ojca (rzadziej także matki), tożsamość świadków. Akty - poprzez konkrety - odsyłają biografa do kolejnych nazwisk i miejsc. Dzięki pozyskanym z metryki wiadomościom można orzekać o kwestiach rodowych, budować nowe hipotezy i dokonywać kwerend w konkretnych kierunkach (nazwiska, parafie, typowane okresy). W ostatnich latach biografia Grabińskiego jest systematycznie dopełniana dzięki m.in. opracowaniom Jakuba Knapa, Krzysztofa Bortnika i Tomasza Pudłockiego, publikowanym głównie na łamach czasopism przemyskich. Niniejszy tekst ma charakter suplementarny w zakresie ustaleń biograficznych z najwcześniejszego okresu życia twórcy, obejmuje także nieznane dotąd kwestie rodowodowe.

1 Na luki biograficzne w opisie materiału wspomnieniowego w opracowaniu monograficznym A. H u tn i k i e w i c z a (Twórczość literacka Stefana Grabińskiego 〈1887-1936). Toruń 1959) oraz nieprecyzyjność podanych tam informacji słusznie zwraca uwagę J. Kna p (wstęp w: J. B e d na r ski, Wspomnienia o Stefanie Grabińskim. Oprac. i do druku podał J. Kn a p. „Litteraria Copernicana” 2013, nr 1, s. 292), pisząc: „Nie będąc przeznaczonym do druku, miało ono [tj. wspomnienie Bednarskiego] przede wszystkim charakter informacyjny, "użytkowy" czy fragmentami wręcz "sprawozdawczy", w mniejszym stopniu zaś par excellence "wspomnieniowy"”.

2 Nie widziała tego aktu także J. Majews ka, autorka najnowszej, bogatej w konteksty monografii Demon ruchu, duch czasu, widma miejsc. Fantastyczny Grabiński i jego świat (Wrocław 2018). 


\section{Metryka chrztu i jej postcedencje}

Akt chrztu Stefana Grabińskiego znajduje się rzeczywiście w księgach parafii greckokatolickiej (cerkwi) w Kamionce Strumiłowej ${ }^{3}$, gdzie czasowo zamieszkiwali jego rodzice. Jest to oczywiście metryka sporządzona w języku łacińskim. Wynika z niej, że Stefan Grabiński urodził się 26 II $1887^{4}$ w Kamionce, w domu pod numerem 247 , ochrzczony został - z wody, wskutek słabego zdrowia - przez księdza miejscowego, Michała Cegielskiego, 13 III tegoż roku. Właściwa ceremonia chrztu odbyła się jednak dopiero 18 VIII, a dopełnił jej... dziadek nowo narodzonego - Józef Grabiński, paroch zamieszkały we wsi Kutkorz ${ }^{5}$. Metryka zawiera informacje o rodzicach: Dionizy Grabiński, syn Józefa i Marii z Dolnickich, oraz Eugenia Czupka ${ }^{6}$ córka Bazylego i Anny z Hauptmannów. Rodzicami chrzestnymi Stefana byli jego stryj Józef, prawnik, wówczas praktykant w sądzie powiatowym w Bursztynie ${ }^{7}$, i jego małżonka Eleonora ${ }^{8}$.

Tych kilka nowych informacji - nazwisk i miejsc - zaczerpniętych $z$ aktu chrztu pozwoliło na dalsze archiwalne poszukiwania. Zdołano ustalić, że ojciec pisarza pochodził z rodziny unickiej, w której silne były tradycje religijne; zarówno ojciec, jak i dziad Dionizego Grabińskiego byli parochami. Supozycja Hutnikiewicza: „ktoś w rodzinie Grabińskich był ponoć duchownym greckokatolickim”, uzyskała potwierdzenie. Dziadek pisarza, Józef, urodził się w 1832 r. ${ }^{10}$ jako Józef Romaniszyn (Romanyszyn) ${ }^{11}$, poślubił w 1856 r. Marię Dolnicką, córkę parocha Andrzeja Dolnickiego (1800 - po 1872) z Glinian, znanego jako „tit[ulares] Consil[iarius] consistorii commisarius ord[ine] ad scholam [Radca tytularny, komisarz konsystorium do spraw szkolnictwa]" ${ }^{12}$, oraz Julianny z Dawidowiczów. W roku 1857 został parochem w Bałuczynie ${ }^{13}$. Tam 15 X 1858 urodził się ojciec pisarza, Dionizy; był

Miasteczko to, leżące około $40 \mathrm{~km}$ na północny wschód od Lwowa, zlokalizowane było w ówczesnym powiecie kamioneckim w Galicji. Dziś nazywa się Kamionka Bużańska i przynależy do Ukrainy. Wypadała wtedy sobota. Wbrew twierdzeniom M a j e w s ki ej (op. cit., s. 13) nie był to dzień mroźny; wedle „Gazety Lwowskiej” (1887, $\mathrm{nr} 43$, s. 4) temperatura powietrza była bliska 0 stopni C, a tylko nad ranem nieznacznie poniżej tej wartości.

5 Kutkorz - wieś pod Buskiem w powiecie kamioneckim obwodu lwowskiego nad rzeką Połtew, około $50 \mathrm{~km}$ na wschód od Lwowa.

6 Właściwe nazwisko w mianowniku brzmi: Czupka, ale bywa ono - wskutek nieoczywistości dopełniacza liczby mnogiej - zniekształcane (z Czupków) i w wielu opracowaniach ma postać Czupek lub nawet Czubek. Bursztyn - miasto w powiecie rohatyńskim na trasie między Lwowem a Stanisławowem.

8 USC Kamionka Strumiłowa / parafia greckokatolicka. Centralne Archiwum we Lwowie (dalej: CAL), f. 201, op. 4, t. 6662, akt urodzenia z r. 1887, k. 192.

9 Hutnikiewicz, op. cit., s. 59.

10 Podstawowe informacje o dziadku pisarza zob. Schematismus universi venerabilis cleri archidioeceseos metropolitanae graeco catolicae [...] na rok 1871. Leopoli, s. 113.

11 Jako Josephus Romaniszyn (w indeksie osób oraz w erracie - Romanyszyn), paroch Bałuczyna, wpisany jest w Schematismus [...] na rok 1858 (Leopoli, s. 100, 228, 256), po tym roku już konsekwentnie jako Josephus Grabiński. Nazwisko Romaniszyn, jako oboczne wobec Grabińskiego, widnieje także w aktach urodzin jego dzieci.

12 Zob. Schematismus [...] na rok 1871, s. 111.

13 Bałuczyn - wieś nieopodal Kutkorza w obwodzie lwowskim, oddalona od Lwowa około 50 km na wschód. 
on pierworodnym synem Grabińskiego i Dolnickiej ${ }^{14}$. Dionizy miał jeszcze dwu braci, którzy przyszli na świat w Bałuczynie: Józefa (17 III 18605), świadka chrztu Stefana, oraz Antoniego (16 X 1861 ${ }^{16}$ ). Maria Grabińska zmarła w połogu 6 XII 1861, mając zaledwie 24 lata ${ }^{17}$. Wdowiec, zgodnie $\mathrm{z}$ zasadą obowiązującą księży greckokatolickich, nigdy nie ożenił się powtórnie. W latach siedemdziesiątych był parochem w Kutkorzu i zapewne tam, około r. 1893, zmarł. Dionizy i Józef byli prawnikami, obaj - w związku z rodzajem zatrudnienia - nader często zmieniali miejsca zamieszkania. O losach trzeciego syna Grabińskich - Antoniego, nie wiadomo.

Matka autora Salamandry, Eugenia Czupkówna urodziła się około 1860 r., była - jak wynika $z$ metryki chrztu jej syna - córką małżeństwa Czupków: Bazylego, urzędnika cesarsko-królewskiego, i Anny z Hauptmannów. Nie udało się dotrzeć do aktu zawarcia małżeństwa między Grabińskim a Czupkówną, ale na podstawie metryki zaślubin jej brata, Juliana Czupki ${ }^{18}$, z Henriettą Kluger można ustalić kilka zasadniczych faktów o tej rodzinie. Czupkowie byli - tak jak i Grabińscy grekokatolikami. Mieszkali w majątku Kozaczówka pod Czortkowem w obwodzie tarnopolskim, gdzie urodził się Julian (1854), a zapewne i Eugenia ${ }^{19}$.

Eugenia Grabińska była uzdolniona muzycznie. Po śmierci męża udzielała lekcji gry na fortepianie i w ten sposób utrzymywała rodzinę; przeżyła śmierć wszystkich swoich dzieci, zmarła po 1936 r. we Lwowie. Henryk Zbierzchowski wspomina ją z r. 1931 (gdy odwiedził pisarza w Brzuchowicach), nazywając Grabińska „najczulszym i najlepszym przyjacielem” syna, jego „opiekunem i towarzyszem w ciężkich, szarych godzinach żywota”, a także „słodką matką [...], siwą jak gołąbek, $z$ oczyma dobrymi, jak jasność wiosennego nieba o poranku" ${ }^{20}$. Wtóruje mu Jerzy Płomieński, który jako gość w lwowskim mieszkaniu Grabińskich tuż przed śmiercią pisarza zapamiętał jego matkę jako: „dystyngowaną starszą panią, srebrzystowłosą, o pięknych rysach twarzy i mądrych, smutnych oczach, pełnych

USC Bałuczyn / parafia greckokatolicka. CAL, f. 201, op. 4-A, t. 96, akt urodzenia z r. 1857, k. 110. Jw., akt urodzenia z r. 1860, k. 118.

Jw., akt urodzenia z r. 1861, k. 186.

Jw., akt zgonu z r. 1861, k. 191.

Wuj pisarza, Julian Czupka (1854-1923), był doktorem obojga praw; wkrótce po zawarciu małżeństwa wyjechał do Stanów Zjednoczonych, mieszkał w Nowym Jorku, gdzie w 1886 r. wydawał humorystyczny periodyk „Osa”; w r. 1889 w Buffalo wraz z warszawianinem H. Nagielem (autorem Tajemnic Nalewek) współpracował przy gazecie „Kukuryku” (umieszczał w niej „Kącik Osy”), od 1891 r. był Czupka redaktorem naczelnym „Polonii”, wydawanej w Baltimore - zob. W. Kru sz ka, Historia polska $w$ Ameryce. T. 5. Milwaukee 1905, s. 5, 7, 12, 15, 26. Uzdolniony literacko, pisał J. C z u pk a wiersze satyryczne, wydał także zbiorek translacji z języka czeskiego: Lwia siła (i kilka innych wierszy). New York 1893.

USC Lwów / parafia rzymskokatolicka św. Andrzeja. Archiwum Główne Akt Dawnych w Warszawie, akt małżeństwa $\mathrm{nr} 54, \mathrm{z}$ r. 1881, k. 411. Nie zachowały się natomiast księgi metrykalne $\mathrm{z}$ lat, na które mogły przypadać zaślubiny Grabińskich, tj. 1884-1886, z parafii greckokatolickiej w Boryszkowcach, właściwej dla Kozaczówki, co nie pozwala na ustalenie dokładnej daty. Grabińscy mogli też poznać się we Lwowie, nie znaleziono jednak potwierdzającej metryki zaślubin w żadnej z lwowskich cerkwi unickich.

H. Z b i e r z c h o w s ki, I po raz czwarty padty na stót karty. „llustrowany Kurier Codzienny” 1931, nr 128 , s. 2-3. 
melancholijnej słodyczy i macierzyńskiej dobroci”21; zachwycony, poświęcił Grabińskiej trzy sporych rozmiarów akapity, gdzie we wzruszających, niezwykle lirycznych słowach opisał jej osobowość i emocjonalny związek z synem.

\section{Miejsca zamieszkania}

Należy sprostować i uzupełnić informacje o miejscach zamieszkania Grabińskich przed i po przyjściu na świat Stefana. Nie jest bowiem prawdą, że z Kamionki przenieśli się od razu do Łąki. Miejsca pobytu tej rodziny wyznaczało zatrudnienie Dionizego Grabińskiego, który był prawnikiem. Właściwie rodzina przyszłego autora Ciemnych sił zmieniała miejsca pobytu średnio raz na dwa, trzy lata. Rekonesans w Szematyzmach (tj. personalnych obsadach etatowych wszystkich urzędów centralnych i lokalnych) $z$ lat $1884-1898^{22}$ dał w miare wiarygodne w tym zakresie informacje. Do roku 1886 Grabińscy mieszkali we Lwowie ${ }^{23}$, gdzie prawdopodobnie brali ślub. Z końcem r. 1886 Dionizy Grabiński otrzymał etat auskulanta (praktykanta) w sądzie powiatowym w Kamionce Strumiłowej ${ }^{24}$, skąd przeniósł się (został przeniesiony) w r. 1889 do sądu w Busku ${ }^{25}$, gdzie pozostawał do 1891 roku. Następnie, w latach 1892-1894, pracował w Borszczowie ${ }^{26}$, a od przełomu 1894 i 1895 r. aż w Jarosławiu ${ }^{27}$ i dopiero tutaj na etacie adiunkta sądowego. W latach 1896-1897 był zatrudniony w Buczaczu ${ }^{28}$, a w r. 1898 - już jako sędzia - w sądzie powiatowym w Łacee ${ }^{29}$. Tam rychło, bo na przełomie 1898 i 1899 r. - zmarł ${ }^{30}$, zapewne na gruźlicę, licząc 40 lat. Po jego śmierci wdowa $z$ czworgiem małoletnich dzieci (najstarszy, Stefan, miał lat 11, najmłodsza córka - 3) oraz z matką, Anną

J. E. Płomieński, Suweren polskiej fantastyki literackiej. Stefan Grabiński. W: Twórcy bez masek. Wspomnienia literackie. Warszawa 1956, s. 118.

Jest to okres przybliżony, ponieważ sporządzanie wykazów odbywało się pod koniec roku poprzedzającego specyfikację, a zmiany mogły nie zawsze być odnotowywane na bieżąco. Szematyzm (wydawany we Lwowie) ma w zasadzie charakter sprawozdania za rok ubiegły.

Dionizy Grabiński (i jego brat Józef) znajduje się w wykazie auskulantów lwowskich - zob. Szematyzm Królestwa Galicji i Lodomerii na rok 1884, s. 52; ibidem, na rok 1885, s. 52.

Zob. ibidem, na rok 1888, s. 50. Badacze - za Hutnikiewiczem - przypisywali Dionizemu funkcję naczelnika sądu w Kamionce, co nie jest zgodne z prawdą (pełnienie takiej funkcji wydaje się niemożliwe, zważywszy na jego stosunkowo młody wiek). W każdym razie w wykazach nie jest on nigdzie wymieniony jako naczelnik sądu, ale jako praktykant.

Zob. ibidem, na rok 1892, s. 51. Busk - miasteczko w Galicji, odległe około 20 km na południowy wschód od Kamionki Strumiłowej, około 60 km od Lwowa.

Zob. ibidem, na rok 1893, s. 88. Borszczów - miasteczko w obwodzie tarnopolskim, ponad $200 \mathrm{~km}$ na południowy wschód od Lwowa.

Zob. ibidem, na rok 1894, s. 64. Jarosław - chodzi o leżące na terenie Polski miasto nad Sanem. Z Borszczowa do Jarosławia musieli Grabińscy przebyć ponad $350 \mathrm{~km}$.

Zob. ibidem, na rok 1896, s. 78. Buczacz - średniowieczne miasto około $70 \mathrm{~km}$ na południe od Tarnopola, nad rzeką Strypa. Tarnopol, Buczacz i Czortków były rejonami rodzinnymi Eugenii Grabińskiej. Podróż z Jarosławia do Buczacza wiązała się z pokonaniem podobnej drogi, jak przy poprzedniej przeprowadzce.

Zob. ibidem, na rok 1898, s. 78. Łąka (zwana Szlachecką lub Rustykalną) - wieś w odległości około $25 \mathrm{~km}$ na wschód od Sambora, malowniczo zlokalizowana na wzniesieniach.

Z uwagi na niedostępność ksiag metrykalnych (zgony) z r. 1898 nie można zweryfikować pozytywnie tej daty, jednakże Szematyzm na rok 1900 już nie odnotowuje Dionizego Grabińskiego, co pośrednio może oznaczać, że zmarł on właśnie w 1898 r. lub z początkiem roku następnego. 
z Hauptmannów Czupkową, przeniosła się do Lwowa. Adnotacje w książkach adresowych pozwalają śledzić kolejne miejsca jej zamieszkania. W roku 1902 jest to ul. Krzyżowa 34a ${ }^{31}$, w 1909 r.: Długosza 8, a następnie 332, rok później - Piastów $18^{33}$. W roku 1913 Eugenia Grabińska nie widnieje w wykazach, natomiast odnotowany jest Stefan, mieszkający wówczas przy ul. Balonowej $1^{34}$. W latach 1914-1915 Grabińska, „wdowa po naczelniku sądowym w Łące”, wraz z czterema osobami wymieniona jest wśród uchodźców wojennych w Wiedniu; mieszka wtedy przy Schinaglgasse $1^{35}$. Książka adresów Lwowa na r. 1916 informuje, że nauczyciel (profesor gimnazjum) Stefan Grabiński mieszka przy ul. Szeptyckich nr $28^{36}$.

\section{Trzy siostry Grabińskie}

W niektórych opracowaniach biograficznych dotyczących Stefana Grabińskiego wspomina się o trzech jego siostrach ${ }^{37}$. Jedna $z$ nich, Maria z Grabińskich Czajkowska, była poetką ${ }^{38}$. Brat wydał pośmiertnie jej wiersze w 30-stronicowym tomiku Życia mego kwiat, dołączając go do przemyskiej edycji swoich Ciemnych sit z 1921 roku. Udało się - śledząc skrupulatnie drogę przemieszczania się małżeństwa Grabińskich - znaleźć akt jej urodzenia. Maria Helena przyszła na świat 30 IV (a nie 10 IV, jak to zanotował w tomiku Stefan Grabiński) 1892 w Borszczowie ${ }^{39}$. Podobnie jak brat, za świadka chrztu miała stryja Józefa i tak samo ceremonię odprawił jej dziadek. Jak pisze Płomieński, bardzo wcześnie wyszła za mąż, zapewne we Lwowie $^{40}$, za nieznanego $\mathrm{z}$ imienia Czajkowskiego; zmarła u końca wojny (21 VIII 1918), w wieku 26 lat, w podlwowskich Winnikach; nie wiadomo, czy stale tam mieszkała, czy może przebywała czasowo na kuracji. Nie udało się dotrzeć do informacji o jej ewentualnej progeniturze.

Zob. Książka adresowa Lwowa [na r. 1902], s. 31. Niektóre biogramy pisarza (zob. m.in. M a j e ws k a, op. cit., s. 58) podają, że w latach „lwowskich” z okresu gimnazjalnego i studenckiego Stefan Grabiński najpierw mieszkał przy ul. Ossolińskich 10. W lwowskich książkach adresowych brak tej informacji, zatem podejrzenie T. Pudło c ki e g o (Środowisko studenckie Stefana Grabińskiego. „Rocznik Przemyski” 2002, z. 2, s. 136-137), iż Grabiński wynajmował - jako lokator - ,jakiś pokój lub kąt”, może być słuszne.

Zob. Wielka księga adresowa dla miast Krakowa, Lwowa i Podgórza, 1909, s. 56.

33 Zob. Ksiażka adresowa Lwowa [na r. 1910], s. 206. Wraz z córką i wnukami mieszka przy ul. Piastów 18 także babka Anna Czupkowa, gdzie adnotowana jest jako wdowa (s. 158).

34 Zob. Książka adresowa Lwowa [na r. 1913], s. 155. Ten adres pisarza nie był - jak sądzę - dotąd ustalony.

35 Zob. Księga pamiątkowa i adresowa wygnańców wojennych z Galicji i Bukowiny 1914-1915 oraz Album pamiatkowe. Cz. 1: Lwów. Wiedeń 1915, s. 82.

Zob. Ksią̇ka adresowa Lwowa [na r. 1916], s. 108. To miejsce zamieszkania Grabińskiego także nie było dotąd znane.

H u tni ki e wi c z (op. cit., s. 60) powołuje się na wspomnienia z r. 1904 księdza Władysława Żaka. Poświęcam jej twórczości osobny tekst: Ztych przeznaczeń rozpostarta księga. O melancholii w poezji Marii z Grabińskich Czajkowskiej (w druku).

39 USC Borszczów / parafia greckokatolicka. CAL, f. 487, op. 1, t. 18, akt urodzenia z r. 1892, k. 181.

40 Pło mi eń s ki, op. cit., s. 120. Nie wiadomo, czy śladami brata zmieniła wyznanie na rzymskokatolickie, czy pozostała przy dawnym obrządku. W księgach adresowych z interesującego nas czasu wymieniana jest nauczycielka Maria Czajkowska - żona inżyniera Czajkowskiego, mieszkająca przy ul. Kurkowej. Ów inżynier to pochodzący z Krakowa, a we Lwowie przebywający stale od 1909 r., „elektroinżynier” Leszek Czajkowski. Trudno zweryfikować tę informację bez dodatkowych kwerend. 
O ile średnia siostra Grabińskiego znana jest i $z$ imienia, i z tego, że była poetką, pamięć o pozostałych dwu zupełnie nie przetrwała. Zdołano jednak wyszukać potrzebne metryki urodzin. 28 I 1890 w Busku przyszła na świat najstarsza z sióstr, Zofia; jej uroczysty chrzest celebrował Józef Grabiński ${ }^{41}$, a świadkami byli: Izydor Zielski, paroch ze Zboiska, i Stefania Wysoczańska, żona parocha z Krasnego. W roku 1910 Zofia Grabińska mieszkała wraz z matką i babką przy ulicy Piastów 18 i w księdze adresowej odnotowana została jako „pomocnica kancelisty” ${ }^{42}$. Zmarła jak wnosić wypada $z$ odręcznej adnotacji uczynionej na akcie jej urodzenia 10 I 1926 w Warszawie. Pod tym kątem przeszukano nekrologię zamieszczaną w „Kurierze Warszawskim”, niestety - bez rezultatu.

Najmłodsza córka Grabińskich miała na imię Jarosława (i drugie imię: Jaryna), które zostało jej nadane zapewne w związku $\mathrm{z}$ miejscem zamieszkania rodziców. Przyszła bowiem na świat właśnie w Jarosławiu 4 III $1895^{43}$. O jej losach niczego nie udało się ustalić poza tym, co ujawnia jej brat: że zmarła w roku $1917^{44}$, w dwudziestym drugim roku życia. O śmierci obu młodszych sióstr Grabińskiego wiedział Hutnikiewicz, który napisał: „W trudnych i ciężkich latach wojny stracił Grabiński dwie siostry. Ich wątłe zdrowie nie sprostało doświadczeniom i próbom czasu"45.

O którejś z trzech sióstr pisarza wzmiankuje Józef Bednarski: „dzisiaj jeszcze przypominaja mi się jej przerażone oczy i sposób tulenia się, chronienia się na ulicy do matki, jak gdyby przelęknionej”" ${ }^{\prime 6}$.

Przyczynki dotyczące rodowodu Stefana Grabińskiego, wczesnych lat jego dzieciństwa oraz danych o rodzeństwie wypełniają kilka luk w jego biografii oraz w kontekstach życiorysowych. Dzięki odnalezieniu metryki urodzenia i innych materiałów archiwalnych można było zrekonstruować peregrynacje jego rodziców, określić stanowiska, jakie Dionizy Grabiński piastował w kolejnych urzędach sądowych, a także ustalić kompletną progeniturę. Wskutek penetracji ksiagg adresowych dopełniono kilka danych, które nie były znane, lub potwierdzono już wiadome.

Kwerendy w zasobach archiwalnych wzbogaciły m.in. wiedzę na temat wyznania ziemiańskiej rodziny pisarza: po stronie ojca byli to księża uniccy, piastujący nierzadko ważne funkcje w Kościele greckokatolickim, podtrzymujący te tradycje. Ojciec Grabińskiego musiał pozostawać im duchowo wierny, czego dowodzą ceremonie chrztów jego dzieci, które to ceremonie powierzał swemu ojcu, a także świadkowie tych uroczystości, będący - wyjąwszy brata - parochami (zwłaszcza Zielscy, dawni znajomi Dolnickich i Grabińskich jeszcze z Glinian). Także rodzina Czupków była unicka. Co sprawiło, że wnuk i prawnuk parochów: Józefa Grabińskiego i Andrzeja Dolnickiego, zmienił wyznanie na rzymskokatolickie, trudno dociec; powody mogły być rozmaite, zarówno narodowościowe (chęć odróżnienia się od Ukraińców), jak

USC Busk / parafia greckokatolicka. CAL, f. 201, op. 4, t. 6306, akt urodzenia z r. 1890, k. 179. Ksiażka adresowa Lwowa [na r. 1910], s. 206.

USC Jarosław / parafia greckokatolicka. Archiwum Państwowe w Przemyślu, zespół 2041, sygn. 7, akt urodzenia z r. 1895, k. 149.

S. Grabiński, Maria z Grabińskich Czajkowska. W: M. z Grabińskich Czajkowska, Życia mego kwiat. Poezje. Przemyśl 1921, s. 6.

Hutnikiewicz, op. cit., s. 73.

Bednarski, op. cit., s. 306. 
i emocjonalne (pragnienie niewyodrębniania się w grupie rówieśników, konflikt $z$ rosyjskojęzycznym katecheta ${ }^{47}$ ); trudno stwierdzić, czy była to decyzja przemyślana, czy spontaniczna ${ }^{48}$. Warto zwrócić uwagę, że w momencie przejścia na inne wyznanie (r. 1905 lub 1906) Stefan Grabiński nie miał nawet 20 lat. Nie wiadomo też, czy zmiany dokonał sam, czy wraz z najbliższymi - z matką i siostrami.

Należy sprostować powszechne przekonanie, że Grabiński dzieciństwo spędził w Łące, $z$ dokumentacji wynika, iż mieszkał tam przez okres niezbyt długi, najwyżej jeden rok, a pobyt ten zakończony był żałobnym akcentem - zgonem ojca. Do klasy pierwszej gimnazjum samborskiego uczęszczał zatem dość krótko; ponadto - jeśli wierzyć wspomnieniom Romana Pollaka - w czasie roku szkolnego mieszkał w Samborze, oddalonym od Łąki o - mniej więcej - $25 \mathrm{~km}$, najpierw na stancji, potem zaś wraz z siostrą (Zofią?), u „sympatycznej babuni”, czyli u Anny Czupkowej na ulicy Lwowskiej ${ }^{49}$. Naukę rozpoczał gdzie indziej, zapewne w Buczaczu, a niewykluczone, że jeszcze w Jarosławiu. Tak częste relokacje Grabińskich mogły wpłynąć ujemnie na jego kontakty $\mathrm{z}$ rówieśnikami, wskutek zmiany otoczenia bowiem stale był on $\mathrm{w}$ grupie nowy, nie miał szans na nawiązywanie trwałych relacji. Prawdopodobnie te doświadczenia wczesnego dzieciństwa wraz ze szczególną wrażliwością i kompleksją duchową ukształtowały charakter przyszłego autora Dziedziny.

\author{
Abstract \\ DOROTA SAMBORSKA-KUKUĆ University of Łódź \\ ORCID: 0000-0002-1943-6694
}

\title{
NOT ONLY ON STEFAN GRABIŃSKI'S BAPTISM CERTIFICATE
}

Archive search queries on Stefan Grabiński and his origin, of which the writer's act of birth was the keystone, harvested in new settlements or specifications that support the hypotheses of his former biographers. As it was settled, Grabiński originated from a family of Greek Catholic origin both from

Zob. R. Polla k, Ze wspomnień o Stefanie Grabińskim. W zb.: Księga pamiątkowa ku czci Konrada Górskiego. Red. A. Hutnikiewicz. Toruń 1967, s. 361. Zob. też Bednarski, op. cit., s. 302.

Pudło cki (op. cit., s. 141) przypuszcza: „to środowisko studenckie, w którym młody Grabiński przebywał na pierwszym roku, przyczyniło się do tego, że prawdopodobnie latem 1906 r. zmienił on wyznanie na rzymskokatolickie. Trudno powiedzieć, co było tego bezpośrednim powodem. Grabiński figurował w księgach uniwersyteckich jako Polak już wcześniej. Może ze względu na liczne tarcia narodowościowe, które często zdarzały się w ówczesnym Lwowie, jak i na uniwersytecie, doszedł do wniosku, że wyznanie greckokatolickie bliższe jest jednak ukraińskości, z która się nie identyfikował? Może miłość do literatury polskiej, w której wielokrotnie to właśnie Kościół rzymskokatolicki utożsamiany jest z etnosem polskim, była także jedną z przyczyn zmiany wyznania?" W tej kwestii na fałszywym tropie jest K. Bortnik (Niedoceniony fantasta. O Stefanie Grabińskim i jego opowiadaniach. „Przemyski Przegląd Kulturalny” 2012, nr 2, s. 85), sugerując, że matka pisarza mogła pochodzić z rodziny rzymskokatolickiej. Jak pokazują dokumenty, nie była to prawda. Sam S. Grabiński wspomina w Wyznaniach („Polonia” 1926, nr 141, s. 13) oraz w tekstach literackich (kreacja Jerzego z Salamandry i Pomiana z Cienia Bafometa), że w dzieciństwie religia była dla niego niezwykle ważnym składnikiem życia duchowego, wskazuje również matkę jako jej animatorkę i strażniczkę. Ta religijność nie musiała jednak wcale łączyć się z rodzajem wyznania, ale $\mathrm{z}$ usposobieniem. 
his father and his mother's side, while his grandfather and grand grandfather were parish priests. The origin was traced back to the third generation, and the dates of births and deaths of Grabiński's sisters-Zofia, Maria (Czajkowska) and Jarosława-were detected.

An attempt at reconstructing the moves of the Grabinski family showed that in the period of Stefan's childhood, in connection with his father's employment, they often changed their whereabouts, which might have influenced Grabiński's subsequent bothering states of alienation. 